\title{
Expectations and Challenges the Implementation of Education Inclusive Programs
}

\section{(A Case Study Research the Implementation of Education Inclusive Programs in SMP 10 Banjarmasin)}

\author{
Hamsi Mansur \\ Lambung Mangkurat University \\ Banjarmasin, Indonesia \\ hamsimansur58@gmail.com
}

\author{
Mastur \\ Lambung Mangkurat University \\ Banjarmasin, Indonesia
}

\begin{abstract}
This research aims to know how the implementation education inclusive programs at the level of middle-high (SMP) school in Banjarmasin South Kalimantan Province. To know how far the education inclusive programs, the researcher used implementation model evaluation countenance. The main data in this study (a) the component preparation (antecedents) of implementation of evaluation education inclusive programs at the level of middle-high (SMP) school in Banjarmasin, (b) the component process (transactions) of implementation of evaluation education inclusive programs at the level of middle-high (SMP) school in Banjarmasin, (c) the component products (outcomes) of implementation of evaluation education inclusive programs at the level of middle-high (SMP) school in Banjarmasin. The model used in this study is Contenance evaluation model. The results showed that (a) on the components of the preparation (antecedents), preparation for the implementation of inclusive education has not planned well, (b) on the component process (transaction) the implementation of inclusive education has not been running effectively, and (c) the component products (outcomes), the results of the implementation of inclusive education is not maximized.
\end{abstract}

Keywords- educational program; inclusive; countenance evaluation component;

\section{INTRODUCTION}

One of the Government-issued policies in addressing equalization of education is a policy about inclusive programs at schools. Inclusive School is a service provided to a child in need of specialized in obtaining a decent education. The Government policy is contained in [1]. The Act provides opportunities to students in need of special education to earn education likes in regular schools. Inclusive programs are a collaboration between the students in need of special study together with normal students and treated like normal students. Seen from the aspect of psychological shows that have a positive impact on school students in need of special. Education inclusive is the implementation of the multicultural education insightful can help learners understand, accept, and appreciate other people of different tribes, culture, values, personality, and physical and psychological disorder.

The presence of the inclusive school is an effort for the alleviation 9-year compulsory education. The completion of this study during 9 years one cause is still the presence of the students in need special who could not complete the primary education because of the existence of the child away from school. In addition, there is a tendency of the ability of parents to fund his son's very minimal.

In general, the existence of extraordinary schools (SLB) is located in the capital district. Whereas, students in need special spread throughout the area (sub-district and village), not only in the capital city of the district. As a result, most of the students in need special, especially the ability of the economy weak, forced her parents not schooled because of the distance of the school (SLB) too far away so hard. On the other hand, If the students in need special were educated at the nearby elementary school, the challenge was the rejection from school by reason of the limitations of the capabilities of the service. In the meantime, during these, there is also a school which does not reject and open with students in need special, but the school has no special escort teacher. The consequence, students attending schools that could potentially leave the class and eventually dropped out of school. These problems may result in failure of the 9-year compulsory education program [2].

Inclusive education policies in Indonesia has lasted approximately 8 years, including organizing inclusive education in the City of Banjarmasin in South Kalimantan. Over time the implementation of inclusive education there are problems found in some Cities, such as Bandung, Medan, and Central Java. In the city of Bandung and Medan for example found problem that could not be accommodated by the school, the curriculum has not been modified to fit students in need special, accessibility has yet to accommodate all the needs of the learners, as well as regular school teacher attitudes towards students in need of special care less.

The next research resulted from Central Java reveals that student management in education inclusive in the province of Central Java assessed is still lacking. This is due to the process of admission of that there is nothing to give limit/quota for the crew on board, the process of identification and assessment of that was not done, and pieces of identification and assessment of that not being available in each school inclusive education pen Organizer.In addition, the inclusive education curriculum management in the province of Central Java is rated is also less 
This is caused because curriculum developed with a modified model in the design of the device, to teach defenders (syllabus, RPP, and evaluation system), while its application inconsistencies. Individual learning Program (PPI) is not given to them, and the assessment report learning process students in need special not arranged in purposes. In addition the same with the management of produce educators on inclusive education in the province of Central Java. This unorganized caused incomprehension of teachers in implementing inclusive education in regular schools. For that, the teachers still need additional supply/training inclusive education program.

Such as conditions in fact not much different from that occurring in the city of Banjarmasin, South Kalimantan. Conducting of inclusive education in the city of Banjarmasin after observation and initial research. The result shows that their confusion about service learning (individual) for students in need of special, the unavailability of special escort teachers, lack of acceptance of teacher attitudes towards inclusive education, and lack of knowledge of the principal and teachers about the procedure of organizing the inclusive education [3]. Even one of the inclusive education program providers the Junior High School does not accept students in need special, except students who have barriers to learning. The reason the school does not yet have a special escort teacher. These findings are certainly less in line with the philosophy of inclusive education.

Based on that data, then the implementation of inclusive education in Banjarmasin need evaluations to be done in a systematic and structured for the sake of accomplishing the goals education for inclusive. The evaluation process is expected to be beneficial for the development of inclusive education programs. Evaluation is seen as a process of determining the outcome some of the planned activities to support the achievement of business objectives. Evaluation of the implementation inclusive education will deep findings of the extent to which the objectives of the SMP 10 program are implemented. Furthermore, the results SMP 10 can be used to determine an appropriate alternative in taking decisions.

The purpose of this research SMP 10 is to know how far the effectiveness of the implementation inclusive education program required the evaluation stressed to aspects of implementation, having regard to the varied standards of the criteria the implementation of inclusive education. To reveal that side obviously needed methods and the best evaluation model and in accordance with the research objectives. From some of the methods and models of evaluation, which are considered in accordance with this research is Contenance Evaluation Model. This emphasis on the evaluation aspects of implementation ranging from preparation, process, and outcomes of a program, as well as consider various criteria and expectations of the people involved in inclusive education programs.

\section{METHODS}

\section{A. Research Method}

Method the used in this research is the qualitative approach. A qualitative approach is used to uncover the facts, circumstances, phenomenon, variable, and circumstances that occurred during the research of walking and presenting data.

The methods used in this research an evaluation with using a model of evaluation Countenance. There is two withheld's election model. First, countenance provides information more description from all phases of the evaluation. Second, the countenance gives more details of the exposure of each stage of the evaluation of the standards used. In the meantime, the subject of this is the whole stakeholder's schools with regard to the implementation of inclusive education in SMP in Banjarmasin, among others headmaster, teacher of field study, teachers of supervising special in need, a committee of the school, and parents of students as the inclusive education programme service users. The object who examined was the implementation of inclusive education programs in the SMP 10 Banjarmasin.

\section{B. Data Analysis}

The analysis data used in this research is qualitative analysis with described each of the data evaluated. Analysis data carried out SMP 10 consistent since the beginning of the collection of data, which in the process is composed of three interrelated phases, namely the reduction of data, data presentation, and conclusion. The process of data analysis is done begin the process until the end of the initial data collection. Data that has been collected through interviews, observations, and analysis of documents is reduced by means of selection, determine the focus, and simplify it. The Design research (countenance) can be described as follows:

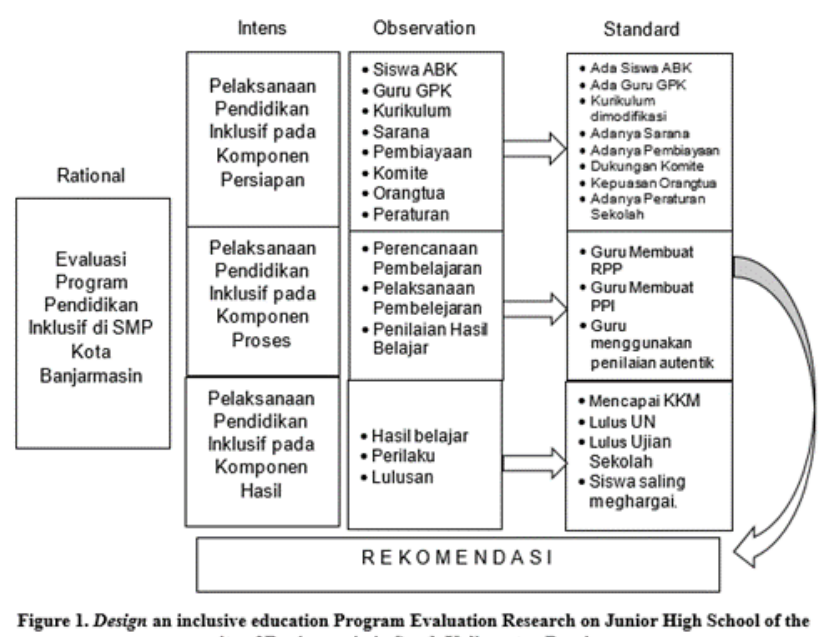

city of Banjarmasin in South Kalimantan Province

\section{RESULTS AND DISCUSSIONS}

The findings of the study expose the overall results of the study which covered the entirety of the data and the analysis and interpretation of the results analysis. Data obtained in this research is qualitative data so that its analysis is also adapted to the shape of the data. As for the picture of the implementation inclusive education programs in the city of Banjarmasin in Junior High School is as follows: 
The scope of input (antecedent) is a recruitment of students in need of special, identification and assessment, special companion teacher recruitment, curriculum, facilities and infrastructure, financing, school committee the student's parents, satisfaction as users, the making of school rules about the standard of organizing and managing the school inclusive, the professionalism of the inclusive school teachers by providing education and training as well as awards for teachers who have a teaching load exceeds the specified limit.

From the mind that all components of the implementation of inclusive education programs in SMP 10 Banjarmasin. In yet plan in good according to the standard criteria of organizing. Aspects of the components of the antecedent many that have not been fulfilled in implementing inclusive education at both schools.

The second is the scope of transactions relating to the ability of teachers in the learning plan for students in need of special education, carry out an assessment of the results of the study. On these components from the results of data analysis in the field turned out to be too many aspects are far from expectations of standard evaluation criteria. As for the aspects referred to among other things: (a) the teacher has not yet compiled a planning study (RPP) corresponding to the characteristics of the students in need special (ABK), (b) special escort teachers have yet to draw up individual learning program (PPI), (c) teachers have not modified the curriculum to suit the needs of students, and (d) yet there is a scoring system has been designed to the students ' ability.

Aim and scope report in this research are: (a) the results of a study in which consists of ranking class and system reports results of the study, (b) social behaviours, and (c) a graduate student National Examination (UN), and the exam Schools whose are able to continue next ahead.

As for the results of inclusive education program data in the city of Banjarmasin, it can be concluded that there are some aspects which have been standard evaluation criteria, but there is also another aspect that still not in accordance with standard evaluation criteria. Some aspects already comply, among others, the behavior of students mutually appreciative one and other, and the students passed the Exam and UN schools. In the meantime, things that are not yet in compliance with the standard is a result study of the student has not met the minimum criteria study (KKM).

There are components of the antecedent shows yet there is relevance in matrix description, i.e., between what is the purpose of observations with outcome observations. Some of the items do not meet the standards of the evaluation criteria, among others, recruitment of students, teacher recruitment, assessment service, modifications to the curriculum, facility, program rewards teachers who have a teaching load exceeds the maximum limit, school rules about the standard of management of education for inclusive, and parental satisfaction.

Component of data transactions is also not yet able to meet the overall evaluation criteria standard. This results of the analysis data indicate that skill of teachers plans learning, the ability of teachers in implementing the learning, and the ability of teachers in conducting an assessment of student learning outcomes students in need (ABK) far from the expected competency. However, the component outcomes are slightly different from the previous components. Within this component, there are a couple of things were in accordance with the standard criteria, but on aspects of the minimum criteria study (KKM), there is still a small part of which do not meet standards so that this can be said of this component has not been implemented to its full potential.

Based on a matrix description on top of the Second, schools need to improve various components and aspects of the holding of inclusive education in order that the management and to convene it at both schools (which already runs 7 years) can be run more effectively. The expectation conducting of inclusive education in both schools can manifest the construction of the five pillars of education, namely improving availability of education services, increasing the affordability of education services, improve quality or the quality and relevance of education services, increasing equality in obtaining education services and enhancing or acquiring the services of security education.

On the aspect of the antecedent (prior to implementation), there are some components that have been run in accordance with the guidelines of the inclusive education, but still many who have not been in accordance with the instructions of the implementation guidelines. Some of these components include:

first, recruitment prospective students. The results showed that in SMP 10 Banjarmasin has granted quotas to admitted. This means that on this aspect of the school has created the opportunity to be able to continue inclusive education. It corresponds to the Permendiknas No. 70 the year 2009 about inclusive education for the students in need special and discerning child is special and exceptional talent in article 2. However, despite giving the students in need special quotes the school admission process have not been doing assessment service.

Second, The available Special Escort Teachers (GPK). The attention of the Government of the city of Banjarmasin in GPK recruitment in schools inclusive education providers at the junior level is still very minimal. On SMP 10 Banjarmasin is not GPK because the existence of an agreement between the school and parents are waging in the system. If the school was forced to recruit teachers with GPK without any help from the Government, while on the other hand, the ability of school funding is very limited, it can be ascertained that GPK is not going to get a monthly salary as other teachers. To resolve this issue, SMP 10 Banjarmasin over-handed the management of students fully in guidance counseling teacher (BK). School teacher gazing $\mathrm{BK}$ can provide guidance and direction to students in needs. Maybe on that side, the teacher can provide service and BK guidance However on the side of learning and educational programs a student will not be possible to be implemented properly.

Implementation guidance, learning, and development of educational programs for students can only be done properly when run by experts, i.e. the set S1 PLB. It is delivered as Delphi the most important derived from the S1 PLB because they know and discuss and understand appropriate services for 
students school's inclusive, both in terms of academic as well as non-academic.

Third, The curriculum modifications in the SMP 10 Banjarmasin yet done well. According to the researchers, the curriculum should oriented students needs so that students don't feel got pressure psychologically.

The fourth, Learning media. Special learning media has not fully held for students in the SMP 10 Banjarmasin. Although a particular opportunity to use media images for students with autism, for other types of ABK is still not available.

The fifth, Financing. Data results show that wages received teacher education coordinator inclusive in SMP 10 has not been adequate. Therefore, the Government should immediately determine and set the policy of waging for the GPK. This needs to be done so as not to conflict with employment law, Ketenagakerjaan, Article 88, Paragraph 4.

The sixth, Comite school. The role of the community is very important to be embodied in the implementation of special needs education because the public has a variety of resources that are required of schools and society as well as the owner of the school on the side of the Government. In SMP 10 Banjarmasin has involved school committee in planning education inclusive. According to [4], the purpose formation of School Committee is the hosts transmit and community initiatives in the operational policy of giving birth and education programs in schools.

The seventh, User satisfaction. Based on the results of the interview with parents in SMP 10 Banjarmasin a lot of things the show's lack of satisfaction. This condition is affected by the holding of inclusive education in both the limited \& minimalist school.

The eighth, Professional Teacher Programs as a pilot project and inclusive school should be the teachers get education and training development for student learning, the students in need special. Such is the case with the award program for the dedicated teachers including teaching load who have exceeded a predetermined threshold. Research results are organized, the Government failed to develop the program. In fact, such programs, as well as the form of the award, also encourages the spirit of working teachers to develop inclusive education the better.

The ninth, school rules about the standard of education for inclusive management. One indication of the school has a commitment in terms of improving and quality assurance is the existence of a mutual agreement which is contained in the regulations of the school. Then the school regulations are footing in terms of organizing. But ironically, the second school that until now have not had such a regulation.

On the aspect of transaction implementation/process, the results of research in the field phenomena is almost the same with antecedent, there are already some components that have been implemented in accordance with the guidelines, but there is a component which is not yet implemented. The components that can be seen in the following description.

First, Teachers at the SMP 10 Banjarmasin have yet to draw up the planning of learning in each subject. Based on PP
19 the year 2005 article 20 stated that: "planning the learning process includes the syllabus and learning implementation plan containing at least the learning objectives, teaching materials, methods of learning, learning resources, and assessment results of the study.

Second, a teacher at SMP 10 Banjarmasin trying to develop learning that is accessible to all students in needs included, but still not effective. According to data analysis, the condition has not been in accordance with the opinion that says that learning in an inclusive school is learning that involves the entire learners including $\mathrm{ABK}$. That is, the teacher should create learning-friendly towards all students.

Third. the study showed that students already have reports of assessment quantitatively in the form of report cards. But, report assessment qualitative in form has not been provided. When in fact, the report of the assessment in inclusiveschools commonly used in determining a rising class of students is based on the achievement of mental prowess in the form of a descriptive.

On the aspect of outcomes, the results of research in the field almost the same as the previous aspects, there are already some components that have been implemented in accordance with the guidelines and also there is not yet. Some components that include: first, SMP 10 Banjarmasin students who have not yet reached standard criteria minimum (KKM) on subjects. The result was the impact of yet unsettled modification assessment for students. According to [5], KKM is an achievement of basic competencies of reference criteria to be achieved by students per-subjects. Students who have not yet reached the value of $\mathrm{KKM}$ is not competence.

Second, Social behavior. Social relationships that occur in the SMP 10 Banjarmasin has been very good. In Junior High School students that 10 State mutual to appreciate one another.

Third in SMP 10 Banjarmasin, whole graduating students in the test and exam national school, no exception for students. Permendiknas No. 70 the year 2009 has given permission for schools inclusive education providers to test the academic ability of students in need with a special needs that has been modified based on their abilities. The existence of this inclusive UN expected each school inclusive education providers can more freely in developing the entire potential to be individuals who are intelligent, skilled, and independent.

The fourth, Inclusive education providers in the City of Banjarmasin have a strategy so that students who pass can continue education to the level of intermediate and above. Continuation education for students is guaranteed by the State because education is a basic need of every human without exception including those with differences in ability (disabled) as enshrined in the Constitution UUD 1945 article 31 paragraph (1).

\section{CONCLUSIONS}

Based on the discussion and results above, the researcher can be drawn some conclusions as follows:

First, there is a component of the preparation (antecedent) implementation of inclusive education has not done well with 
planning. It was pointed out by there are still some aspects of the antecedents that have not been conducted in accordance with standard evaluation criteria such as identification and assessment students, recruitment teachers, curriculum, facilities and infrastructure, school rules, awards, user, as well as financing.

Second, there is a component process (transaction) the implementation of inclusive education has not been implemented effectively. In this component, its implementation has not been in accordance with what the expectations and standards of the criteria of evaluation. Among some of the expectations that have not been suitably contained on competence teachers in learning plan with Individual Learning Program (PPI) for students in need of special, next the curriculum has not been modified, the use of media and learning resources, the use of methods and learning strategies, and assessment criteria do not comply with the guidelines of the implementation of inclusive education.

Third, there are components of products (outcomes), the results of the implementation of inclusive education have not been fullest. On this component there is some component has not been in accordance with what the expectations and standards criteria of evaluation. Hopes that unresolved outcome is student learning outcomes, while aspects of behavior and graduates are in compliance with the expectations and criteria for stakeholders.

\section{REFERENCES}

[1] Kemendikbud. Undang Undang Republik Indonesia Nomor 20 tahun 2003 tentang Sistem Pendidikan Nasional.

[2] Direktorat Pendidikan Luar Biasa. (2003). Mengenal Pendidikan Terpadu/Inklusi. Jakarta: Ditjen Dikdasmen.

[3] Rahim dan Mansur. (2013). Sikap Kepala Sekolah dan Guru Terhadap Pendidikan Inklusif di Kota Banjarmasin. Laporan Penelitian, Lembaga Penelitian, Universitas Lambung Mangkurat Banjarmasin.

[4] Dadang G. (2015). Pengantar Pendiidkan Inklusif. Bandung: Refika Aditama.

[5] Mulyono Abdulrahman. (2005). Landasan Pendidikan Inklusif dan Implikasinya dalam penyelenggaraan pendidikan inklusif. Bandung: Rosada, Patton, Michel Quinn. Metode Evaluasi Kualitatif, terjemahan Budi Puspo Priyadi. Yogyakarta: Pustaka Pelajar. 